NASA/TM-2001-210941
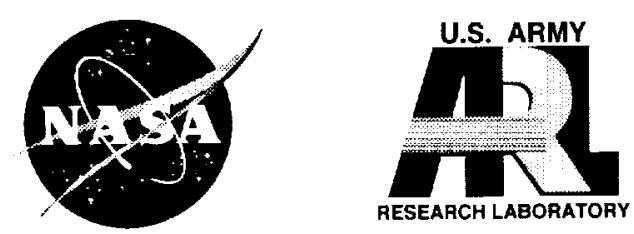

The Effect of Journal Roughness and Foil Coatings on the Performance of Heavily Loaded Foil Air Bearings

Kevin C. Radil

U.S. Army Research Laboratory, Glenn Research Center, Cleveland, Ohio

Christopher DellaCorte

Glenn Research Center, Cleveland, Ohio 
Since its founding, NASA has been dedicated to the advancement of aeronautics and space science. The NASA Scientific and Technical Information (STI) Program Office plays a key part in helping NASA maintain this important role.

The NASA STI Program Office is operated by Langley Research Center, the Lead Center for NASA's scientific and technical information. The NASA STI Program Office provides access to the NASA STI Database, the largest collection of aeronautical and space science STI in the world. The Program Office is also NASA's institutional mechanism for disseminating the results of its research and development activities. These results are published by NASA in the NASA STI Report Series, which includes the following report types:

- TECHNICAL PUBLICATION. Reports of completed research or a major significant phase of research that present the results of NASA programs and include extensive data or theoretical analysis. Includes compilations of significant scientific and technical data and information deemed to be of continuing reference value. NASA's counterpart of peerreviewed formal professional papers but has less stringent limitations on manuscript length and extent of graphic presentations.

- TECHNICAL MEMORANDUM. Scientific and technical findings that are preliminary or of specialized interest, e.g., quick release reports, working papers, and bibliographies that contain minimal annotation. Does not contain extensive analysis.

- CONTRACTOR REPORT. Scientific and technical findings by NASA-sponsored contractors and grantees.
- CONFERENCE PUBLICATION. Collected papers from scientific and technical conferences, symposia, seminars, or other meetings sponsored or cosponsored by NASA.

- SPECIAL PUBLICATION. Scientific, technical, or historical information from NASA programs, projects, and missions, often concerned with subjects having substantial public interest.

- TECHNICAL TRANSLATION. Englishlanguage translations of foreign scientific and technical material pertinent to NASA's mission.

Specialized services that complement the STI Program Office's diverse offerings include creating custom thesauri, building customized data bases, organizing and publishing research results ... even providing videos.

For more information about the NASA STI Program Office, see the following:

- Access the NASA STI Program Home Page at $h t t p: / / w w w . s t i . n a s a . g o v$

- E-mail your question via the Internet to help@sti.nasa.gov

- Fax your question to the NASA Access Help Desk at 301-621-0134

- Telephone the NASA Access Help Desk at $301-621-0390$

- Write to: NASA Access Help Desk NASA Center for AeroSpace Information 7121 Standard Drive Hanover, MD 21076 
NASA/TM-2001-210941
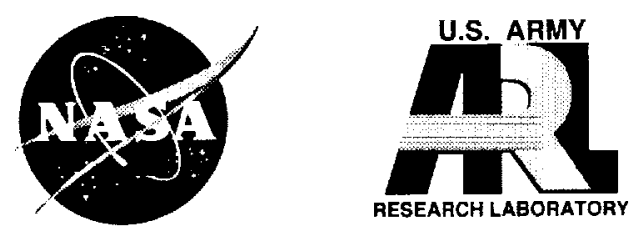

\section{The Effect of Journal Roughness and Foil Coatings on the Performance of Heavily Loaded Foil Air Bearings}

Kevin C. Radil

U.S. Army Research Laboratory, Glenn Research Center, Cleveland, Ohio

Christopher DellaCorte

Glenn Research Center, Cleveland, Ohio

Prepared for the

56th Annual Meeting

sponsored by the Society of Tribologists and Lubrication Engineers

Orlando, Florida, May 20-24, 2001

National Aeronautics and

Space Administration

Glenn Research Center 


\section{Available from}

NASA Center for Aerospace Information 7121 Standard Drive Hanover, MD 21076
National Technical Information Service 5285 Port Royal Road Springfield, VA 22100

Available electronically at http://gltrs.grc.nasa.gov/GLTRS 


\title{
The Effect of Journal Roughness and Foil Coatings on the Performance of Heavily Loaded Foil Air Bearings
}

\author{
Kevin C. Radil \\ U.S. Army Research Laboratory \\ Glenn Research Center \\ Cleveland, Ohio 44135 \\ Christopher DellaCorte \\ Glenn Research Center \\ Cleveland, Ohio 44135
}

\begin{abstract}
Foil air bearing load capacity tests were conducted to investigate if a solid lubricant coating applied to the surface of the bearing's top foil can function as a break-in coating. Two foil coating materials, a conventional soft polymer film (polyimide) and a hard ceramic (alumina), were independently evaluated against as-ground and worn (run-in) journals coated with NASA PS304,

a high-temperature solid lubricant composite coating. The foil coatings were evaluated at journal rotational speeds of $30000 \mathrm{rpm}$ and at $25^{\circ} \mathrm{C}$. Tests were also performed on a foil bearing with a bare (uncoated) nickel-based superalloy top foil to establish a baseline for comparison.

The test results indicate that the presence of a top foil solid lubricant coating is effective at increasing the load capacity performance of the foil bearing. Compared to the uncoated baseline, the addition of the soft polymer coating on the top foil increased the bearing load coefficient by $120 \%$ when operating against an as-ground journal surface and $85 \%$ against a run-in journal surface.
\end{abstract}


The alumina coating increased the load coefficient by $40 \%$ against the as-ground journal but did not have any affect when the bearing was operated with the run-in journal. The results suggest that the addition of solid lubricant films provide added lubrication when the air film is marginal indicating that as the load capacity is approached foil air bearings transition from hydrodynamic to mixed and boundary lubrication.

\section{Introduction}

Compliant foil air bearings operate by generating a self-acting hydrodynamic air film between the stationary inner top foil and the surface of the rotating shaft. Because ambient air functions as the lubricant, foil bearings do not have the same speed and temperature limitations imposed on oil lubricated rolling element bearings and, therefore, can be used at extreme temperatures (to $650^{\circ} \mathrm{C}$ ) and speeds well above 3 million DN (ref. 1). To capitalize on these advantages, research is underway to incorporate compliant foil air bearings into high-speed rotating machinery such as turbochargers, auxiliary power units (APU's), and gas turbine engines (ref.2).

The rotor-bearing system proposed for several high temperature, oil-free applications consists of state-of-theart foil bearings coupled with rotors coated with a wear resistant solid lubricant composite coating, NASA PS304. The foil bearings belong to the Generation III class of foil 
air bearings and have demonstrated in load capacity tests an empirical load coefficient, $\mathscr{Z}$, equal to 1.0 based on the Rule of Thumb (ROT) model proposed in reference 3. The PS304 solid lubricant coating's purpose is to reduce the sliding wear and friction that occurs on the top foil and rotor during start-up and shutdown in the absence of an air film (refs 4 and 5). Endurance test results from start-stop cycles indicate that the coating provides bearing wear lives well in excess of requirements for turbomachinery applications (ref 6).

Recent room temperature load capacity tests performed in the authors' lab on Generation III bearings and PS304 coated journals have exhibited load coefficients of 0.3 instead of 1.0 as previously measured. An ensuing investigation determined that the discrepancy resided with the journals, specifically, the surface finish of the PS304 coating .

In both series of load capacity tests that resulted in $\mathscr{Z}=1.0$ and $\mathscr{Z}=0.3$ the journals were prepared identically by first applying the PS304 material using plasma spraying followed by grinding the as-sprayed surface with a 500 grit diamond wheel to a final average surface roughness of $0.8 \mu \mathrm{m}$. However, the earlier tests that exhibited high load capacity $(\mathscr{I}=1.0)$ were conducted with the same PS304 coated journals that were previously subjected to high temperature 
endurance stop-start cycles. This is important for three reasons.

First, repeated high temperature rubbing associated with each start-stop cycle polishes the surface of the asground coating and generates a thin oxide layer that is smooth, dark, glossy and functions as a solid lubricant. Measurements on this run-in surface (i.e., oxide layer) with a profilometer confirm that the rubbing wear cycles decreased the initial average roughness of the as-ground coating surface from $0.8 \mu \mathrm{m}$ to $0.05-0.2 \mu \mathrm{m}$, very close to the $0.05-0.1 \mu \mathrm{m}$ range considered for optimum bearing performance. Second, it is believed that the localized start-stop rubbing may also generate better conforming surfaces between the bearing top foil and the coating surface. Third, the high temperature sliding causes a transfer of solid lubricants from the PS304 shaft coating to the top foil thereby producing a solid lubricant film that leads to good bearing performance (ref. 7).

An investigation into the cause of the $0.8 \mu \mathrm{m}$ surface finish of the as-ground PS304 coating identified voids, i.e. porosity, created in the coating during the plasma spray process. The presence of open pores typically leads to an unfavorable surface finish when standard grinding techniques are used. For example, as mentioned previously, machine grinding the as-sprayed coating with a 500 grit diamond wheel results in an average surface finish of approximately 
$0.8 \mu \mathrm{m}$. The average surface finish can be improved to $.1-.2 \mu \mathrm{m}$ by following the initial grinding with a more elaborate process of using 600 grit sandpaper, $9-15 \mu \mathrm{m}$ diamond paste and $0.008 \mu \mathrm{m}$ alumina. However, these additional steps are time consuming and costly.

The concern for the surface finish of the PS304 coating is warranted due to its connection with a phenomenon known as galling. Referred to as scuffing or scoring in the internal combustion engine community galling is a failure mechanism characterized by the formation of asperity microwelds between surfaces in sliding contact. It is believed that galling of the top foil and the nickel constituent in the coating is playing a role in limiting load capacity in the same way severe galling between piston rings and liners leads to engine seizure.

The susceptibility of a foil bearing to galling stems from its reliance on a very thin film of air, nominally 5um under normal operating conditions, that separates the top foil and shaft surface. If the average surface finish of the rotor coating is on the same order of magnitude of the air film a load less than the bearing's designed load capacity will instigate local asperity contact with the top foil, resulting in hot spots, friction welding, and galling. The high asperities can also prevent full separation of the top foil from the rotor surface resulting in a bearing 
operating in a mixed lubrication regime. In either case galling will occur once contact is initiated.

Ruscitto et al. proposed another explanation for the relationship between surface roughness and foil bearing load capacity over twenty years ago (ref. 8). In their report they speculated that rough surfaces contain relatively large microscopic voids that provide alternate paths of escape for the air molecules that otherwise would be used to generate and sustain the hydrodynamic air film. This explanation is plausible but is not relevant to this situation because the pores in the PS304 are not interconnected and probably do not assist in any additional or parasitic leakage of air. Even though galling can transpire at any time, given the right conditions, its most pronounced affect on bearing load capacity will be while the coating is in the as-ground condition. Therefore, until the coating and bearing experience the required number of high temperature startstop cycles to produce the thin oxide layer, generate conforming surfaces, and build-up a lubricious transfer film on the top foil galling must be alleviated in order to insure maximum performance of the foil bearing.

The purpose of this paper is to report on a possible solution to sustaining the designed load capacity of a foil bearing while using PS304 in an as-ground condition. The concept to be evaluated is to place a coating directly onto the top foil to inhibit galling and thus allowing the foil bearing to support its designed maximum load. Two coatings, 
a soft polymer (polyimide) and a hard ceramic alumina, were chosen for the study. Their effectiveness was evaluated by conducting a series of room temperature load capacity tests on foil bearings with coated top foils against ground and run-in PS304 coated journals. Room temperature was selected as the best test temperature because it presents the most severe galling condition and does not prompt oxide formation on the surface of the coating. To establish a baseline, uncoated top foils were also tested under the same conditions.

\section{Experimental Apparatus/Procedure}

\section{Foil Bearings}

The Generation III class foil bearings used in the tests are shown in figure 1 and are nominally $35 \mathrm{~mm}$ in diameter, $25 \mathrm{~mm}$ long (or wide) and made up of several layers of nickel-based superalloy foils. The top foil supports the hydrodynamic gas film while the underlying foils, known as bump foils, provide the elastic and compliant support structure for the top foil. The bump foils also provide Coulomb damping to the bearing through frictional microsliding with the top foil and adjacent surfaces. There are other foil bearing designs in commercial use that utilize overlapping leaves and perforated spring foils. The results presented in this paper should also be relevant to these different designs. 


\section{Test Journals}

The test journals shown in figure 2 are nominally $35 \mathrm{~mm}$ in diameter, $84 \mathrm{~mm}$ long and made from a nickel-based superalloy. The journal is an improvement over the previous two-piece design that used a heat dam and test journal secured with a tie bolt (ref. 9). The new journal eliminates the need for a tie bolt by combining the heat dam and test journal into one part. This provides a $40 \%$ weight savings and a more rotordynamically stable test rig. A $0.25 \mathrm{~mm}$ deep undercut is machined on the journal to accommodate the deposition of the PS304 solid lubricant coating. The journals have twelve equally-spaced threaded holes for in-place, high-speed, dynamic balancing.

For the tests with run-in journals, 1000 start-stop endurance cycles under a $10 \mathrm{kPa}$ load at $538^{\circ} \mathrm{C}$ were completed using an identical Generation III bearing that was not associated with the tests. This separate bearing was used to avoid the development of a lubricious transfer film on the three test top foils or to generate conforming surfaces. Therefore, any differences in load capacity results reflect changes in the PS304 coating surface finish and perhaps chemical composition and/or the presence of the top foil coating

\section{Top Foil Coatings}

The polymer (polyimide) and ceramic (alumina) coatings were applied to the bearing top foils prior to installation and assembly of the bearing. The polymer material is a 
commercially available polyimide based dry film lubricant that provides a low coefficient of friction, excellent adhesion and resiliency and long wear life. The top foil was coated by spraying the polymer with an atomizer gun to a final thickness of $25.4 \mu \mathrm{m}$ and cured according to the manufacturer's directions.

The alumina was applied to the top foil using a sputtered deposition to produce a coating thickness of $25.4 \mu \mathrm{m}$ according to the procedures described in reference 10. This material was chosen because it demonstrated promising lubricating properties during previous partial-arc bearing endurance tests (ref. 11) and also high temperature rigid gas bearing tests (ref. 12).

\section{Test Apparatus/Procedure}

The high-speed test rig used to conduct the tests is shown in figure 3 and is described fully in reference 9. The rig consists of a drive shaft that is supported by two hybrid ceramic ball bearings that are lubricated by oil jets and cooled by temperature controlled water. An impulse turbine attached to the drive shaft is capable of driving the shaft to rotational speeds up to $70000 \mathrm{rpm}$. Referring to figure 4, radial loading of the bearing is accomplished via a vertical cable system with one end attached to the bearing and the other to a pneumatic load cylinder mounted below the test rig. A rod attached to the bearing loader is used to relay the bearing torque to a load cell. 
Testing commenced by first placing the bearing on the journal and then accelerating the rig to a rotational speed of $30000 \mathrm{rpm}$. The speed was held constant for a few minutes in order to thermally stabilize the test rig. A chart recorder continuously monitored and displayed the bearing torque signal and the shaft rotational speed. The rig was then accelerated by a few thousand rpm and the pneumatic load cylinder was used to apply a starting load equal to half of the expected load capacity according to the ROT model. When the desired load was reached the rig was decelerated to the final speed of $30000 \mathrm{rpm}$ and held for 5 minutes unless there were indications of bearing failure. In this paper foil bearing load capacity is defined as the maximum load supported by the bearing while still operating at constant speed and steady-state conditions. The chart recorder output shown in figures 5 and 6 better elucidate this definition of load capacity. The two traces in figure 5 a represent speed and torque output from a bearing supporting a moderate load and operating in a stable condition. The spikes in the torque data are caused by sporadic noise from the data acquisition system. Conversely, the speed and torque traces shown in figure 6 reflect a bearing operating close to its maximum load capacity. The erratic behavior exhibited by these traces is indicative of intermittent surface asperity contact between the top foil and the coating. While operating at this load condition frequent speed corrections, in response to the fluctuating 
bearing torque, were needed in order to maintain the test speed of $30000 \mathrm{rpm}$.

If failure didn't occur the speed of the test rig was again increased by a few thousand rpm and an additional $22 \mathrm{~N}$ (5.0 Ib) was applied. The rig speed was reduced to $30000 \mathrm{rpm}$ and the load sustained for another $5 \mathrm{~min}$. This methodology of loading the bearing in $22 \mathrm{~N}(5.0 \mathrm{lb})$ increments with 5 min. hold periods was continued until speed and torque readings indicated that the hydrodynamic film was beginning to rupture. When this occurred the load was returned to the previous stable test condition and a smaller load increment of $4.4 \mathrm{~N}(1 \mathrm{lb})$ was used.

\section{Test Results and Discussion}

The test results for the various top foil coating conditions are summarized in Table 1 . It is clearly evident from the data that the top foil coatings and the PS 304 surface finish, either separately or in combination, have a direct effect on the load coefficient of a foil bearing. The as-ground PS304 coating, vulnerable to galling because of its high surface roughness and exposed nickel constituent, consistently produced the lowest load coefficients. The baseline bearing's load coefficient of $\mathscr{I}=0.33$ falls significantly short of the $\mathscr{I}=1$ design point for the Generation III class foil bearings thus initiating the present research (on foil break-in coatings). The two candidate break-in coatings tested in this study, alumina and the soft polymer, exhibited anti-galling 
characteristics when paired with the as-ground coating but at varying degrees of effectiveness. Alumina's presence on the top foil increased the load coefficient $40 \%$ from 0.33 to 0.47. The polymer coating's effect on the load coefficient was more pronounced than the alumina as it expanded the margin over the baseline by $120 \%$, from 0.33 to 0.73 .

The polymer's superior performance may classify it as a better anti-galling agent but it is believed that a significant portion of the coefficient's increase is due to the polymer's solid lubricant properties. When operating the bearing close to its load capacity the air film is marginal indicating contact between surface asperities. During sliding contact minute wear particles are generated and introduced into the air film causing a transition from a purely hydrodynamic bearing to one that may also be in a state of quasi-hydrodynamic powder lubrication as explained by Heshmat (13). Based on this assumption, the small increase in the load coefficient caused by the alumina coating is probably an indication that, for this application, it is a less effective solid lubricant.

The tests also demonstrated that PS304 in the run-in condition plays a major role in defining the load coefficient of a foil bearing. When the baseline foil bearing was tested against the run-in PS304 coating the load coefficient improved $70 \%$ over the as-ground result from $\mathscr{I}=0.33$ to $\mathscr{I}=0.56$. The run-in shaft coating had the same effect on the bearing with the alumina coated top foil 
as it increased the coefficient $21 \%$, from $\mathscr{Q}=0.47$ to

$I=0.56$ but, when compared to the baseline, the alumina coating was inconsequential as both exhibited coefficients of 0.56 . Continuing the trend when paired with the run-in shaft coating the foil bearing with the polymer coating realized a $43 \%$ load coefficient increase from $\mathscr{T}=0.73$ to $\mathscr{I}=1.05$. If run-in results for the polymer and baseline are compared there is an $85 \%$ increase, from $\mathscr{I}=0.56$ to $I=1.05$, in the load coefficient caused by the coating's ability to perform as a solid lubricant.

The success of run-in PS304 at improving the foil bearing's load coefficient can be attributed to the presence of the thin complex oxide/lubricant surface layer formed during the high temperature sliding cycles of the stop-start endurance tests. The oxide layer alleviates the galling failure mechanism by separating the nickel constituent from the top foil and its smooth surface finish allows for a much thinner air film to be tolerated. Furthermore, as with the polymer coating, the oxide layer produces minute wear particles that act as a solid lubricant. However, based upon the baseline and alumina coating results, achieving a coating surface as smooth as the oxide layer does not automatically guarantee an adequate bearing load coefficient. Other additional factors such as the formation of a lubricious transfer film on the top foil and generating 
conforming surfaces through high temperature start-stop cycles appear to be essential for optimum bearing performance.

The test results of the polymer and alumina coatings against the as-ground surface suggests that top foil coatings can be used to increase bearing performance by inhibiting the onset of galling. However, it is evident from the polymer coating results that if high temperature foil break-in coatings are to be used they must possess anti-galling and solid lubricant properties. Also, since the PS304 coating surface finish plays a major role in the performance of a foil bearing, concurrent work is needed on improving application and/or surface preparation methods.

\section{Conclusions}

1. The current practice of using plasma spraying to apply the PS304 composite results in a porous coating that limits the load coefficient of foil bearings. Further research is needed to identify alternate deposition techniques that produce higher density coatings.

2. The test results for the polymer and alumina coatings indicate that break-in foil coatings that inhibit galling can, at varying degrees, increase the bearing load coefficient. Coatings that possess solid lubricant properties further increase the load coefficient by providing a solid lubrication 
component when the bearing is operating under boundary and mixed lubricating conditions.

3. To maximize performance, foil bearings operating against PS304 coated shafts together must undergo high temperature start-stops in order to produce the smooth oxide layer, conforming surfaces, and the lubricious transfer film on the bearing's top foil.

\section{References}

1. Heshmat, H.: "Advancements in the Performance of Aerodynamic Foil Journal Bearings: High Speed and Load Capability," ASME Jour. Of Trib., Vol. 116, pp. 287295, April, 1994.

2. Heshmat, H., Walton, J.F., Dellacorte, C., and Valco, M.: "Oil-Free Turbocharger Demonstration Paves Way to Gas Turbine Engine Applications," Presented at the ASME International Gas Turbine and Aeroengine Congress and Exhibition, Munich, Germany, May 8-11, 2000, Paper No. $2000-G T-620$.

3. DellaCorte, C., and Valco, M.J.: "Load Capacity Estimation of Foil Air Journal Bearings for Oil-Free Turbomachinery Applications," Tribology Transactions, Vol. 43, 2000, pp. 795-801.

4. Dellacorte, C., and Edmonds, B.J.: "Preliminary Evaluation of PS300: A New Self-Lubricating High Temperature Composite Coating for Use to $800^{\circ} \mathrm{C}$, NASA TM-107056, 1995. 
5. Dellacorte, C., and Fellenstein, J.A.: "The Effects of Compositional Tailoring on the Thermal Expansion and Tribological Properties of PS300: A Solid Lubricant Composite Coating," NASA TM-107332, 1996.

6. Dellacorte, C., Valco, M.J., Radil, K.C. and Heshmat, H.: "Performance and Durability of High Temperature Foil Air Bearings for Oil-Free Turbomachinery," NASA TM-2000-209187, 1999.

7. Dellacorte, C.: "The Evaluation of a Modified Chrome Oxide Based High Temperature Solid Lubricant Coating for Foil Gas Bearings." NASA TM-1998-208660, 1998.

8. Ruscitto, D., McCormick, J. and Gray, S.: "Hydrodynamic Air-Lubricated Compliant Surface Bearing for an Automotive Gas Turbine Engine. I - Journal Bearing Performance." NASA CR-135368, April, 1978.

9. Dellacorte, C.: "High Speed Test Rig for Use to $700^{\circ} \mathrm{C}$ and 70,000 rpm." NASA TM-107405, 1997.

10. Lei, J.F.: "Advances in Thin Film Sensor Technologies for Engine Applications", ASME Paper No. 97-GT-458, 1997.

11. Dellacorte, C., Fellenstein, J.A. and Benoy, P.A.: "Evaluation of Advanced Solid Lubricant Coatings for Foil Air Bearings at 25 and $500^{\circ} \mathrm{C} . "$ NASA TM-1998206619 .

12. Murray, S.F.: "Research and Development of High Temperature Gas Bearings. Volume II: Selection and 
Evaluation of Gas Bearing Materials in Argon at $900^{\circ} \mathrm{F}$ and $1400^{\circ} \mathrm{F}^{\prime \prime}$, NASA Contract No. NAS3-9433, 1969.

13. Heshmat, H.: "The Rheology and Hydrodynamics of Dry Powder Lubrication." Tribology Transactions, Vol. 34, 1991, pp. 433-439.

Table 1. Bearing load coefficients for coated foils running against PS304 in the ground and run-in condition.

\begin{tabular}{|c|c|c|c|}
\hline \multirow[t]{2}{*}{ Foil coating } & \multirow{2}{*}{$\begin{array}{c}\text { Foil Coating } \\
\text { Roughness, } \\
\text { sum Ra }\end{array}$} & \multicolumn{2}{|c|}{ Load coefficient, I } \\
\hline & & $\begin{array}{c}\text { As-ground, } \\
\text { PS } 304\end{array}$ & $\begin{array}{c}\text { Run-in, } \\
\text { PS304 }\end{array}$ \\
\hline Polymer & 0.90 & 0.73 & 1.05 \\
\hline Ceramic (Alumina) & 0.15 & 0.47 & 0.56 \\
\hline (Baseline) & 0.10 & 0.33 & 0.56 \\
\hline
\end{tabular}

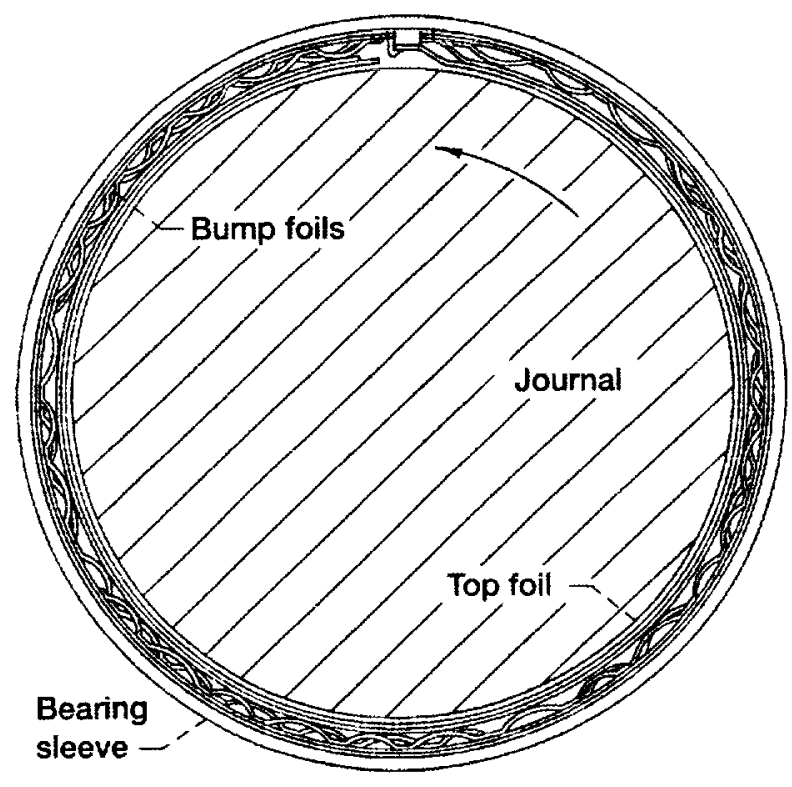

Figure 1.-Schematic of Generation III foil air bearing. 


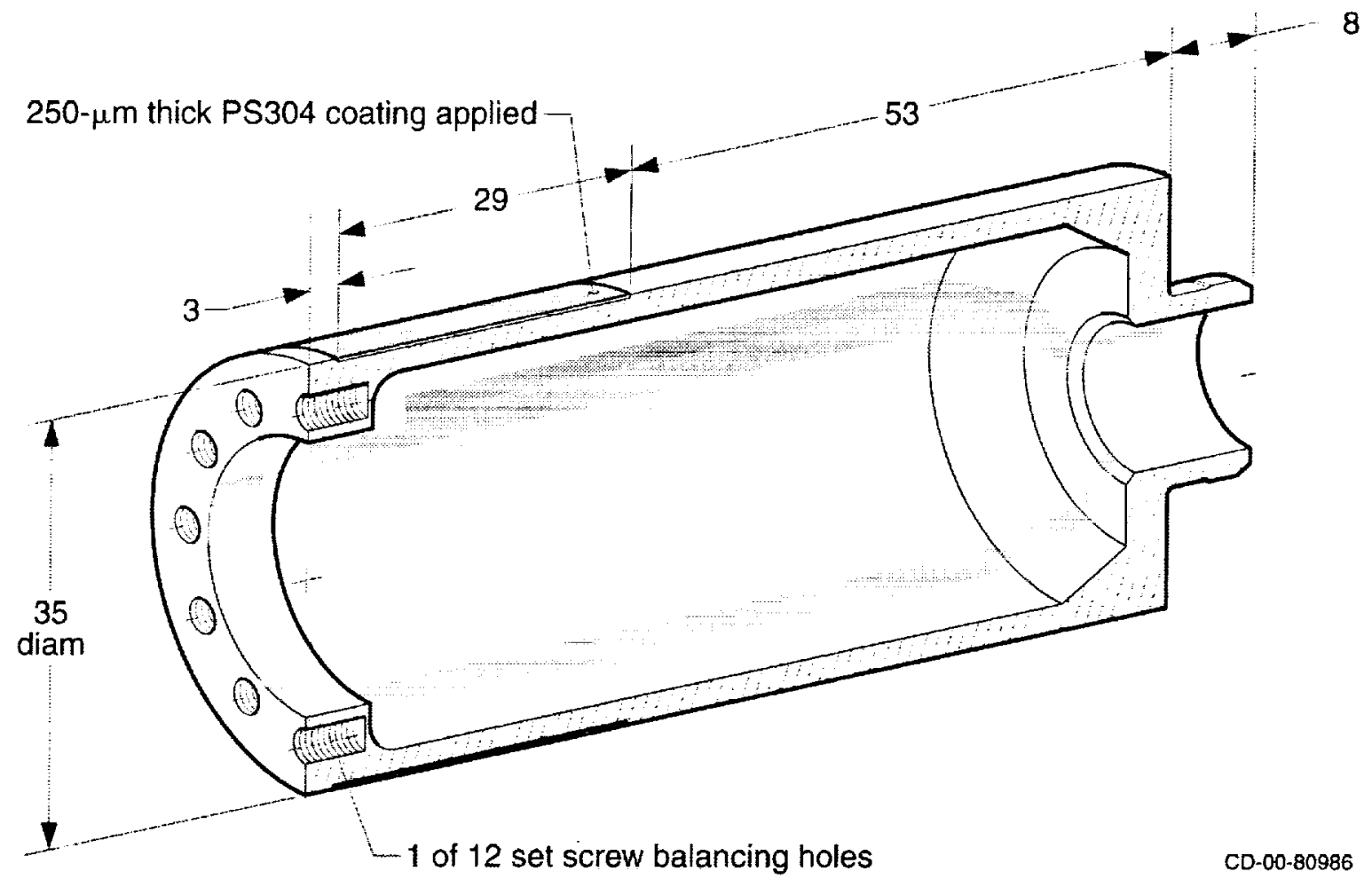

Figure 2.-Schematic of the modified test journal for the high-temperature, high-speed foil air bearing test rig. Measurements in $\mathrm{mm}$. 


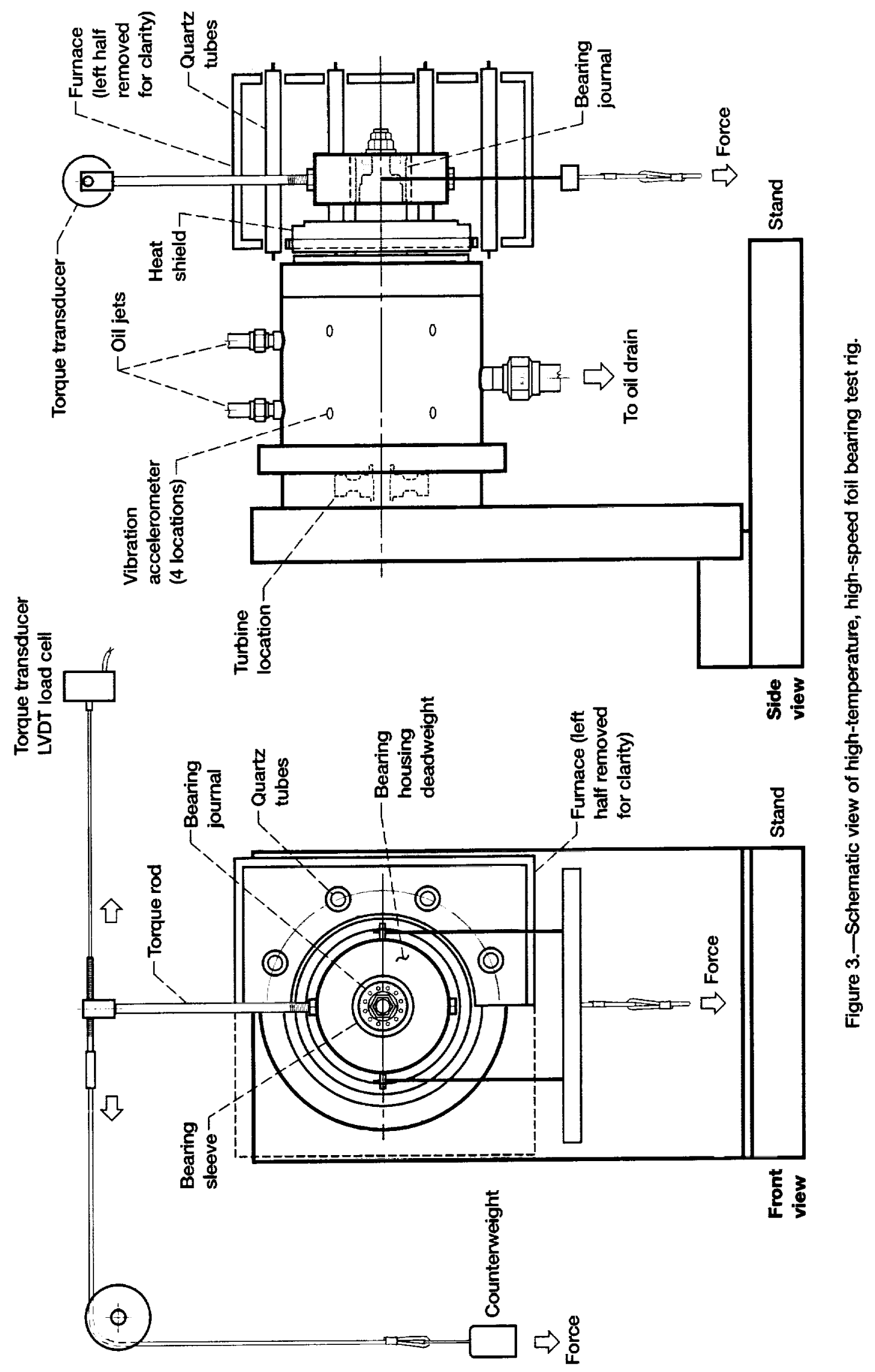




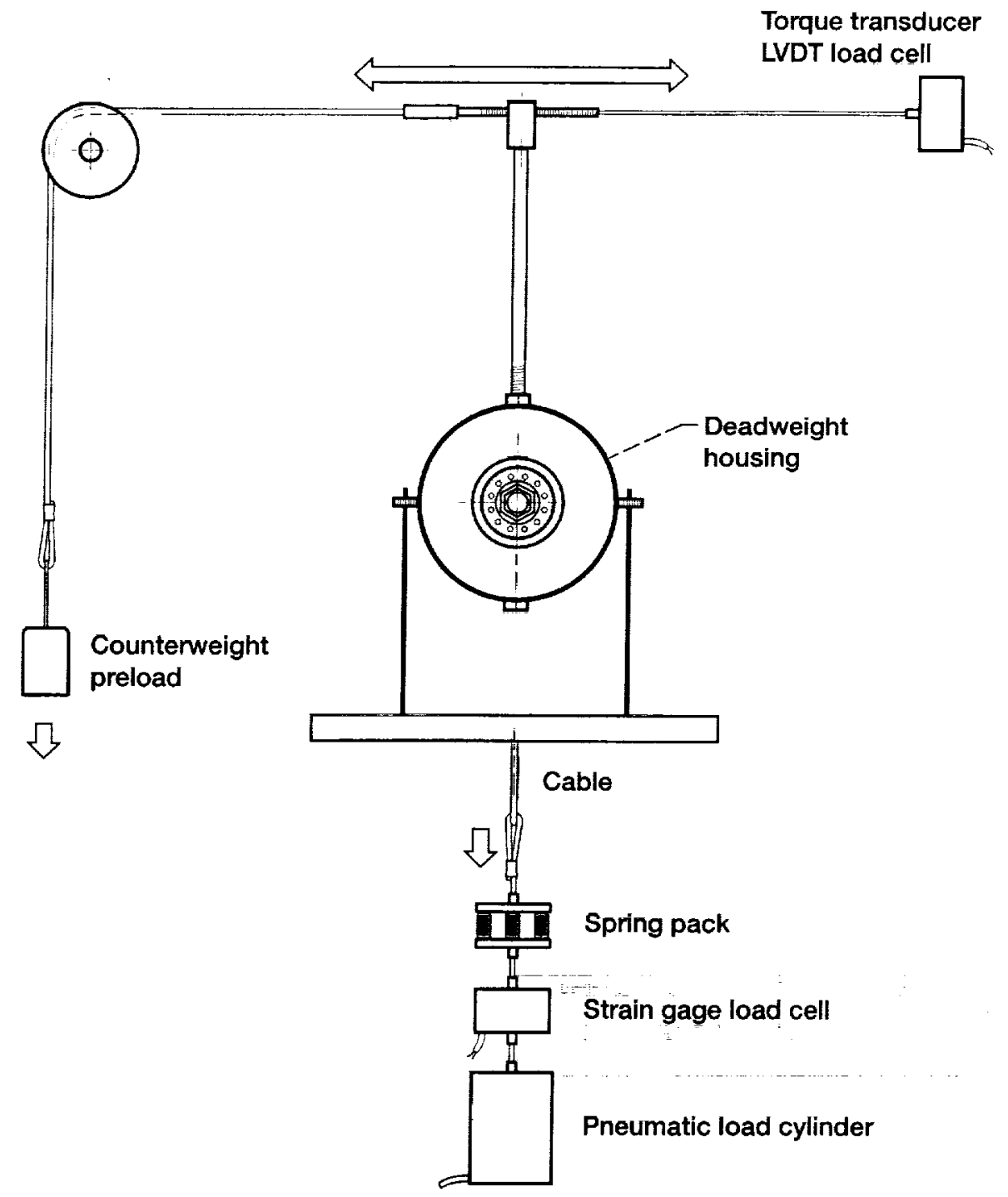

Figure 4.-Test rig partial front view showing torque and load measurement system. 


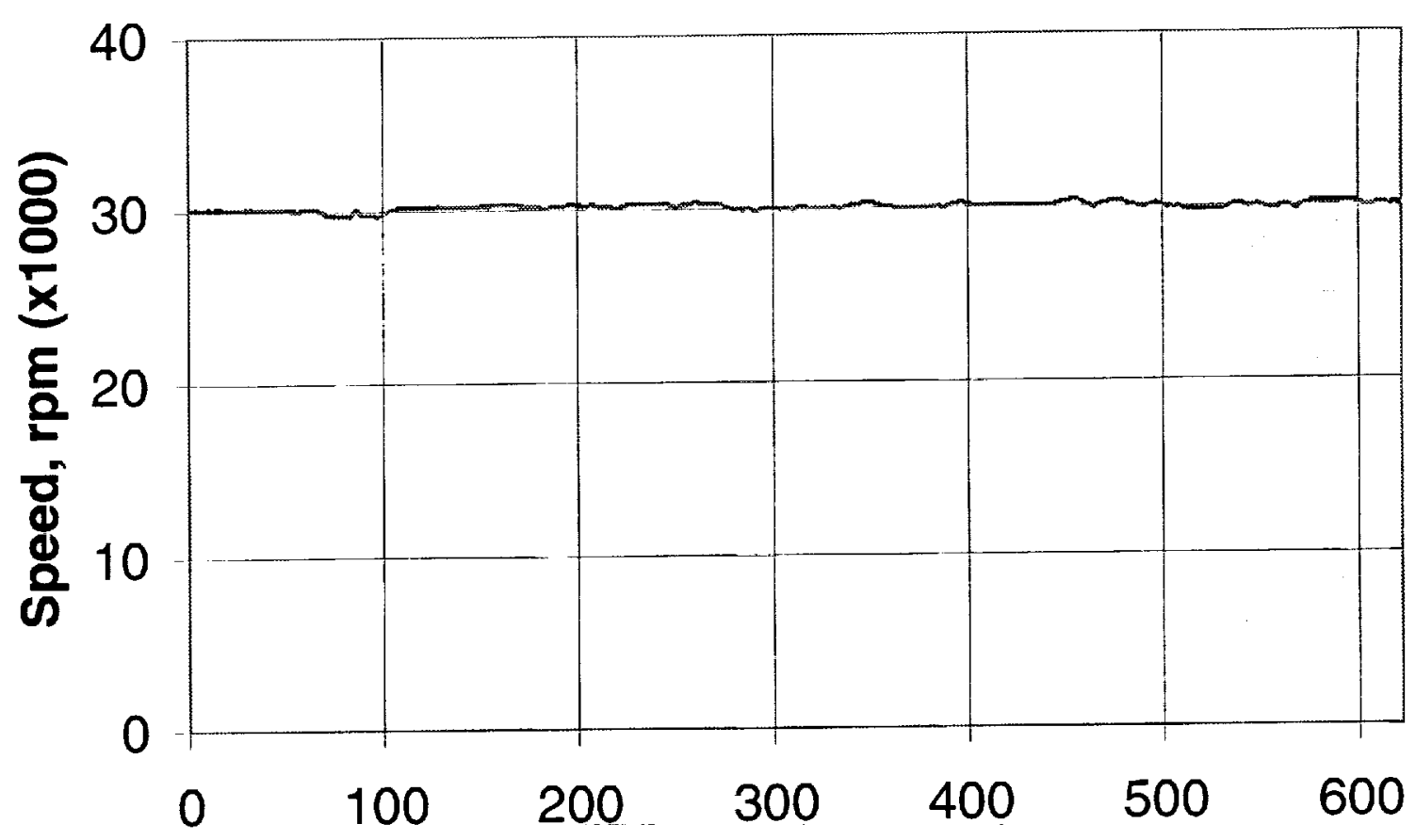

(a)

Time, seconds

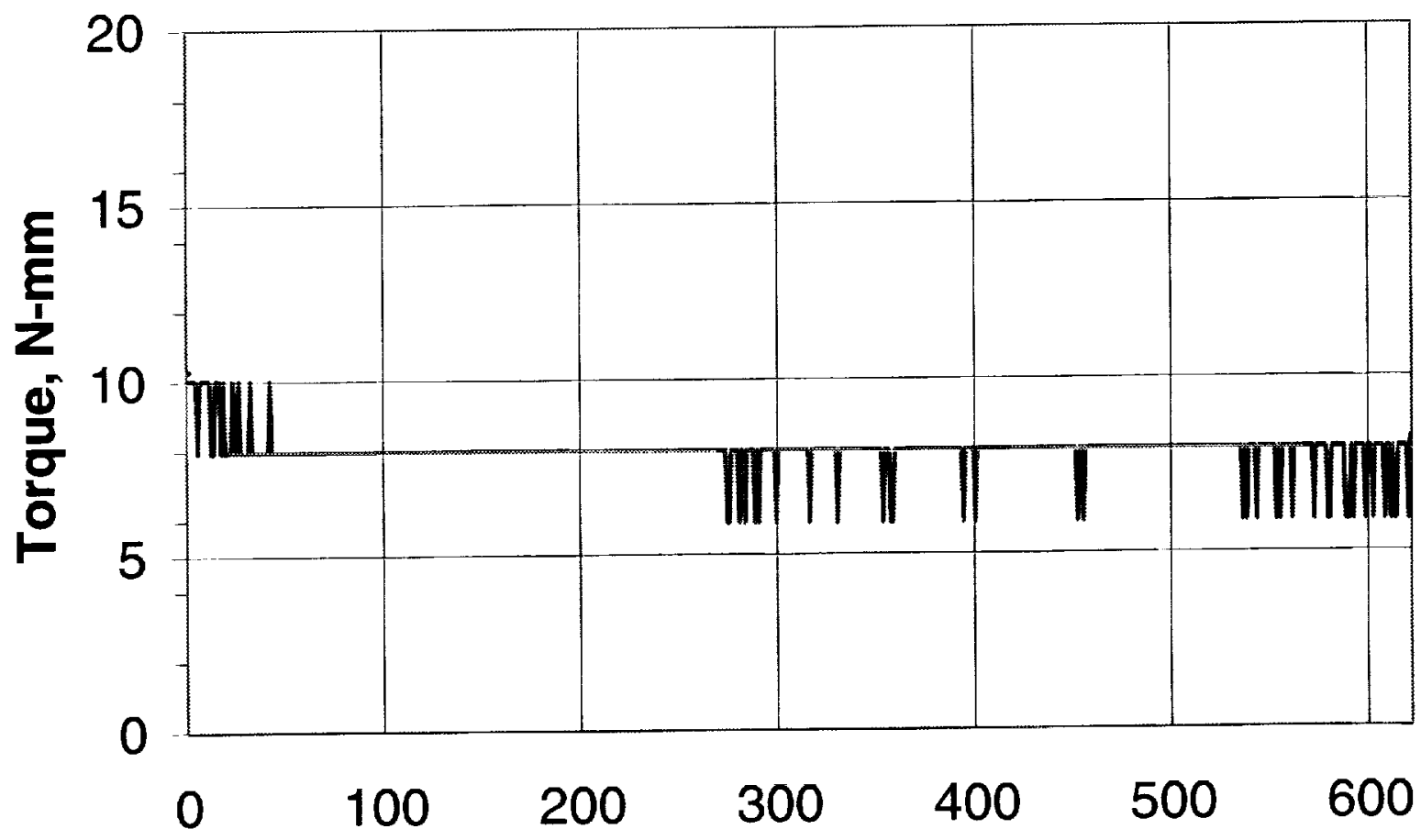

(b) Time, seconds

Figure 5.-Graphs illustrating a foil air bearing operating in a stable condition at $30000 \mathrm{rmm}$ and supporting half of its load capacity. (a) Speed. (b) Torque. 

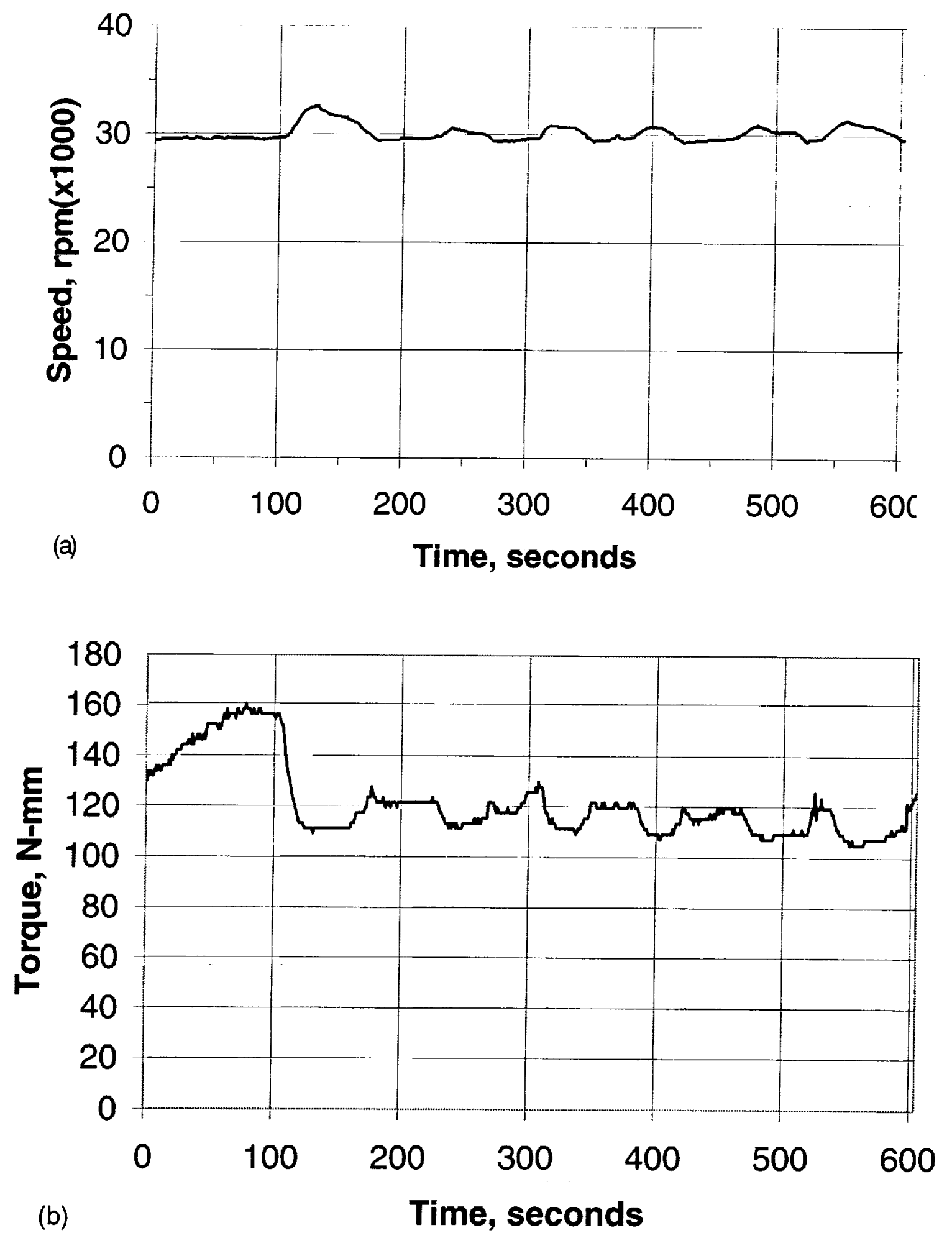

Figure 6.-Graphs illustrating the erratic behavior of a foil air bearing operating at $30000 \mathrm{rpm}$ and supporting close to its load capacity. (a) Speed. (b) Torque. 

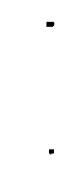

.

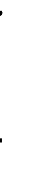

.

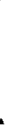




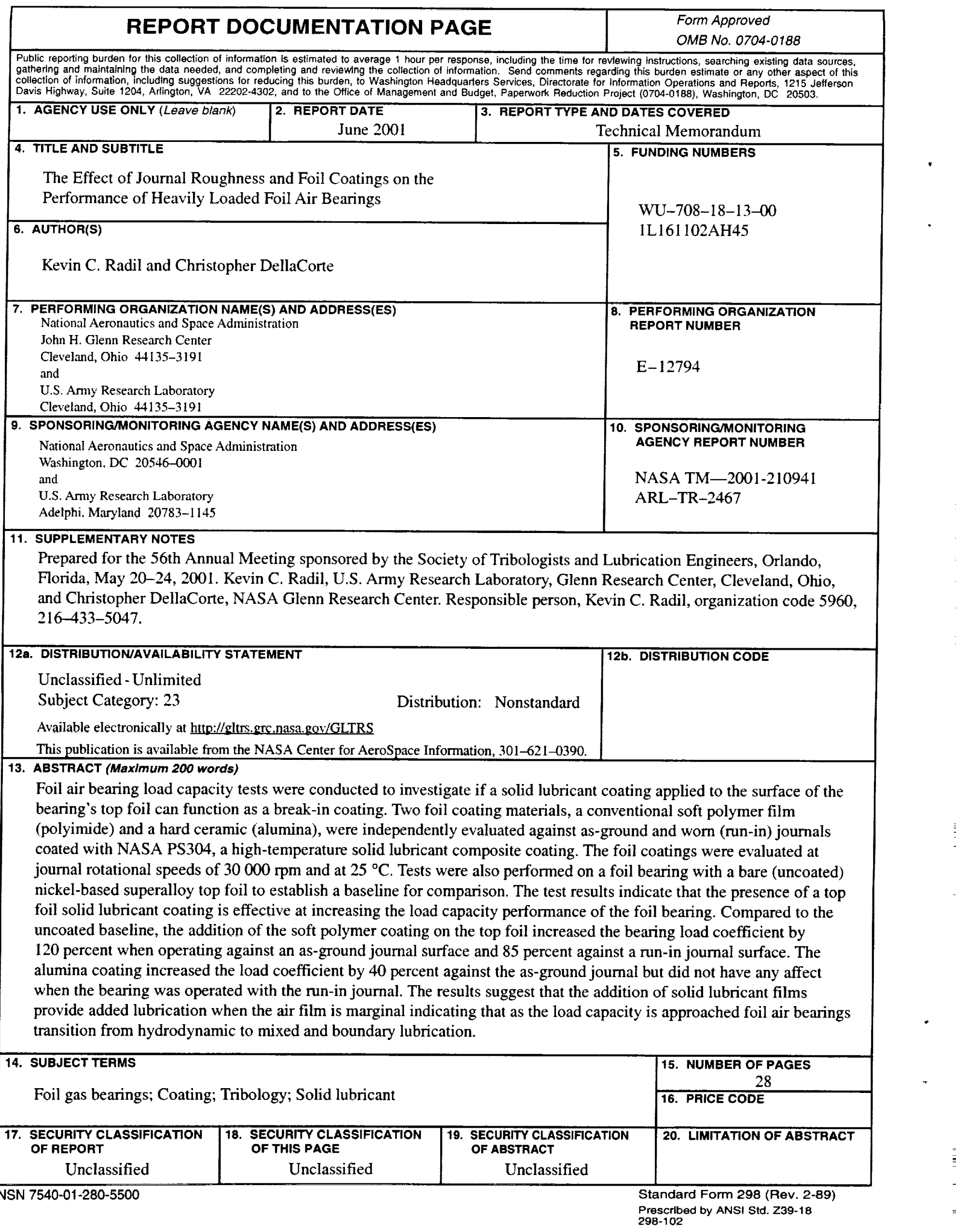

